\title{
ÎNCERCĂRI DE ANALIZĂ MOTIVAŢIONALĂ A UNOR TERMENI PASTORALI DIN AROMÂNĂ
}

\author{
IOANA IANCU
}

\section{CONSIDERAŢII ASUPRA METODEI ANALIZEI MOTIVAȚIONALE}

În Curs de lingvistică generală, Ferdinand de Saussure lansează conceptul de semn lingvistic şi principiul de arbitrar al semnului lingvistic. El observa atunci că între cele două feţe ale semnului lingvistic, semnificantul şi semnificatul, nu există nicio legătură naturală. Totuşi, el admitea, că în cazul onomatopeelor şi al cuvintelor onomatopeice, ,,alegerea semnificantului nu este întotdeauna arbitrară”. La fel stau lucrurile şi cu exclamaţiile. Asemenea semne lingvistice însă, sunt ,de importanţă secundară”, deci neprimejdioase pentru teza enunţată (Saussure 1998: 87-88).

După cum observă Jean Philippe Dalbera (2006: 18), prin arbitrar, Saussure înţelege nemotivarea, ,,adică arbitrar prin comparaţie cu semnificatul cu care nu are nicio legătură naturală în realitate. Dar şi el admite că această distincţie arbitrar / motivat nu este bipolară, dar că există grade de motivare: semnul poate să fie relativ motivat. Astfel vingt este nemotivat, dar dix-neuf nu se află în acelaşi grad pentru că el evocă termenii din care se compune şi altele care i se asociază”.

Aşadar, din costatarea lui Dalbera, se înţelege că Saussure nu neagă la modul absolut motivarea.

În continuarea studiului său, Dalbera aduce în discuţie concepţii lingvistice referitoare la motivarea semnului lingvistic. Referindu-se la P. Guiraud, Dalbera evidenţiază ideea că, atunci când este creat un nou semn lingvistic, acesta „nu are nimic arbitrar". A se vedea în acest sens creaţiile de cuvinte din perioada actuală, din limba franceză, precum informatician, souris 'mouse'.

„Contradicţia arbitrar-motivat nu este de fapt după Guiraud decât una aparentă. Ea se rezolvă, dacă vrem să admitem, prin revărsarea unui al treilea termen: convenţia. În perspectiva lui Guiraud, semnul nu poate fi la început decât motivat; dar folosirea acestui semn se operează nu sub controlul permanent al acestei motivaţii, ci în mod unic prin faptul convenţiei care se instaurează în sânul comunităţii. Pornind de la momentul în care folosirea este convenţională, rolul motivaţiei trece în plan secund" (Dalbera: 19-20). 
Prin uzitarea frecventă a unui termen creat prin motivare, vorbitorii pierd din vedere de ce este motivat. În concluzie, ,trăsătura motivat şi trăsătura arbitrar a semnului nu sunt nimic altceva în definitiv decât descripții a două stări succesive ale dezvoltării acestuia" (ibidem: 20). Iar creaţia lexicală, cum spune mai departe Dalbera, ,este un fenomen care intervine în orice moment şi nu este deloc trimis la originea timpului limbilor" (ibidem: 23 ).

Metoda analizei motivaţionale este adoptată relativ recent şi de lingviştii români.

După cum aflăm din lucrarea Sinteze de dialectologie română, a autorilor Nicolae Saramandu si Manuela Nevaci, metoda analizelor motivationale în lingvistică s-a impus în urma apariţiei hărţilor lingvistice motivaţionale, în Atlasul limbilor Europei. În opinia lor, asemenea hărţi ,ajută la lămurirea sau corectarea unor etimologii din limbi particulare şi oferă un model de interpretare pentru hărţile din atlasele naţionale şi chiar regionale". Astfel, hărţile de motivaţie scot în evidenţă dinamica limbii, prea puţin cunoscută până acum din perspectiva motivării semnului lingvistic. Trebuie să precizăm că este vorba de termeni pe care vorbitorii simt nevoia să-i „,remotiveze” după o perioadă de timp în care referentul s-a opacizat (Saramandu/Nevaci 2013: 84). Cei doi autori au aplicat această metodă în lucrarea citată, în analiza unor termeni din limba română prin comparaţie cu termenii corespunzători din limbile romanice. Dintre cuvintele analizate ne-au atras atenţia în mod special trifoi, lipitoare, iepure de câmp.

În acest context, profesorul Cristian Moroianu, de la Universitatea din Bucureşti, în lucrarea Motivarea formală a relaţiilor semantice. Sinonimii analizabile, propune specialiştilor în domeniu o serie de studii privitoare la motivarea cuvintelor create prin derivare, la sinonimia lexicală analizabilă, la structura derivativă şi, nu în ultimul rând, la relaţiile semantice. Autorul demonstrează că „,relaţia de sinonimie lexicală analizabilă poate fi considerată prin structură derivativă/afixală şi savantă/ afixoidală a componentelor sale, un aspect al motivării semnului lingvistic" (Moroianu 2016: 17). Noua viziune asupra relaţiilor semantice cunoscute conferă studiului său o modernitate binevenită.

\section{INTERPRETĂRI MOTIVAŢIONALE ALE UNOR TERMENI PASTORALI DIN AROMÂNĂ}

Pornim în analiza noastră de la Atlasul lingvistic al dialectului aromân (autor: Nicolae Saramandu, editor: Manuela Nevaci), de unde am preluat lexemele respective. Primul volum s-a publicat la Editura Academiei Române, Bucureşti, 2014, fiind cea mai amplă cercetare de geografie lingvistică pentru dialectul aromân. Este rodul unor îndelungate cercetări de teren efectuate de Nicolae Saramandu în Grecia, Albania, R. Macedonia, Bulgaria, cuprinzând într-o imagine de ansamblu întregul areal aromânesc. Sunt cuprinse în lucrare toate graiurile aromâneşti, care pot fi identificate şi descrise, pentru prima oară în mod amănunţit, 
pe baza prezentului atlas. Reţeaua de localităţi are 61 puncte de anchetă în Bulgaria, R. Macedonia, Grecia, Albania (32 în Grecia, 12 în Albania, 9 în R. Macedonia, 8 în Bulgaria) şi 276 de hărţi lingvistice.

Un bogat material dialectal, inedit, oferă şi volumele al II-lea şi al III-lea ale Atlasului lingvistic al dialectului aromân (Editura Academiei Române - în manuscris), realizat de Nicolae Saramandu, în colaborare cu Manuela Nevaci.

În cele ce urmează, vom încerca o astfel de analiză pentru corespondenţii, din dialectul aromân, ai termenilor căpuşă, caş, câine ciobănesc, strungă şi burduf.

\section{HARTA 636. CĂPUŞĂ, pl. 'tique' [910]}

Comentăm forma de singular de la chestiunea 910 [Cum se cheamă gângania care trăieşte mai ales pe oi, se înfige în piele şi suge sânge până se umflă?].

S-au obţinut următoarele răspunsuri: cârlej; ţimurâ; căţămor.

cârléję; -léj [m.] 15; cărléj li; cărléjur [m.] 16

Termenul este atestat în DDA cu forma cârléjq, având ca etimon bg. kqrlédzq. Pentru acest termen sunt date drept sinonime lexemele că4imór, -mórĭ cu sensul de 'căpuşă mare' şi căpúşe, pl. căpúşe, cu varianta căpúşq. Forma cârléjq este ocurentă în graiurile aromâneşti din Gopeş şi Molovişte. În albaneză există termenul kërléshj/e cu sensul 'încăierare', 'încăibărare', care ar sugera încleștarea căpuşei în părul animalelor (DAR/FSR s.v.). În bulgara contemporană, există termenul кърлеж cu sensul de 'căpuşă' (DBR/БPP s.v.). Luând în considerare semantica acestor lexeme, am putea crede că avem de a face cu un termen motivat.

ţimúrâ; -múri 41 în DDA.

Termenul este prezent în graiul pindean din Giurgea şi nu se află înregistrat

căţămórq; -mór 49;

Termenul este prezent în graiul pindean din Cuţufleani. Un termen asemănător, căčimór , este atestat în DDA cu sensul de 'căpuşă mare'. Acest lexem mai poate avea şi sensul de 'ghemotoc de păr încârligat', neatestat în DDA, dar transmis nouă, în cadrul unei anchete dialectale, din ianuarie 2019, de către subiectul Cavachi Viorica. Existenţa unui asemenea sens ne permite să lansăm ipoteza că termenul respectiv este motivat.

Alte variante de sensuri ale termenului căcimor se regăsesc la Nicolae Saramandu, în colaborare cu Manuela Nevaci, Atlasul lingvistic al dialectului aromân, vol. II, cap. „Note”, Editura Academiei Române, Bucureşti, 2019 (sub tipar):

2: cặcimúórứ, -mưóri 'alt soi de căpuşă care se înfige în pielea oii' .

7, 19: câcimorư, -mórì 'căpuşă mai mică, se înfige în pielea mieilor'.

8: câcimórư, -mórì 'căpuşă care se înfige în coada oii'.

17: [slavii macedoneni spun:] cărléj. 
În dacoromână, cuvântul căpuşă este definit astfel: CĂPÚŞ̆ $\breve{A}$, căpuşe, s. f. I. (La pl.) Gen de artropode parazite din clasa arahnidelor, care se înfig în pielea animalelor şi a omului şi se hrănesc sugându-le sângele (Ixodes); (şi la sg.) animal care face parte din acest gen. $\diamond$ Expr. Ce-i în guşă, şi-n căpuşăa, se zice în legătură cu un om sincer; care spune tot ce gândeşte. II. 1. (Bot.) Ricin. 2. Mugur de viţă, din care se dezvoltă coardele şi rodul; ochi1. - Cf. alb. këpushë (DEX s.v.). În DELR termenul este atestat astfel: CĂPUŞĂ [ar. căpuşe ,artropod parazit; căpşună”, mr. căpuşă „,artropod parazit; mărgele, mătănii”] s.f. „,artropod parazit care se înfige în pielea animalelor şi a omului, sugând sângele; mugur de viţắ ricin - tique; bourgeon de vigne; ricin; (ar.) tique; fraise" 1649 (antrop.). Et. nes., probabil «- -cap + -uşă S. Puşcariu, DR 2, 1921-1922, 594 (posibil), DA (posibil), REW 1668, SDLR, C. Poghirc, TILR II, 338 (posibil), cf. sp. capullo „,căpuşă” (< capillo ,pălărie” + cogulla ,glugă”) CDER 1396 (caz în care alb. këpushë ar fi împrumutat din română), sau el. de substrat (înrudit cu alb. këpushë), care ar putea proveni din i.-e. *kap- ,vierme, omidă” (cf. sanscr. kapana „vierme, omidă”, gr. $\kappa \alpha ́ \mu \pi \eta$,omidă”, let. kâpe ,un fel de omidă”, kâpars, kâpurs „,crisalidă, larvă, omidă”) Russu, Etnogenezei, 289, Brâncuş, VA, 56-58 (posibil), i.-e. *kap- „cap” (cf. lat. caput) sau i.-e. *kap- ,a prinde” (cf. lat. capere) Brâncuş, VA, 56-58 (improbabil ca urmare a dificultăţii de a explica derivarea lui këpushë pe teren albanez, întrucât -ushë nu se ataşează la rădăcini verbale, v. Xhuvani, Qabej, Prapashtesat, 105, 167) // Alb. këpushë Densusianu, HLR I, 352; lat. *cap(a) < capere „a apuca, a prinde”, cf. sp. caparra (cu - p- păstrat în aragoneză), gascon gabar „căpuşă” (pentru asocierea semantică între ,a apuca, a prinde” şi „căpuşă”, cf. grapă ,unealtă agricolă făcută din spini” care are şi sensul regional „,ăpuşă”) Giuglea, CR, 215-221 (apud DELR s.v.).

Emanuela Dima descrie sensul propriu, 'arahnid parazitar cu abdomen mare' (DA s.v.) şi cel figurat, 'mugurul viţei de vie' (DA s.v.), al termenului căpuşă (Dima 2013: 96-97). Autoarea atrage atenţia că termenul ar putea fi format prin derivare cu sufixul -uşă de la un radical moştenit cap (< lat. caput), *cap- (< lat. capio) sau de la radicalul *kap 'vierme, larvă-insectă'. În sprijinul acestor afirmaţii, îi menţionează pe lingviştii Sextil Puşcariu (Puşcariu, DR IV: 1369) şi Ioan Iosif Russu (Russu 1970: 147). Subliniem părerea lui Grigore Brâncuş (Brâncuş 1983: 570) potrivit căruia că termenul căpuşă din română este foarte probabil ,un vechi derivat cu sufixul -uşă, de origine traco-iliră”, dar că radicalul cap „este greu de precizat".

HARTA 637. CAŞ 'fromage frais' [911]

Discutăm forma de singular de la chestiunea 911 [Ce se face din laptele de oaie, după ce ai pus cheag în el şi l-ai stors?]

Răspunsul care ne interesează şi pe care îl vom analiza este caş $\stackrel{\iota}{l}$ dúlţi.

caş ư dúlţi 28 , caş ư dúlţi 52 
Forma caş $\stackrel{u}{l}$ dúlţi este ocurentă în graiul pindean din Veria şi în graiul fărşerot din Horopani. Între formele din cele două puncte, în care se vorbesc graiuri diferite ale dialectului aromân, nu există diferenţe la niciun nivel al limbii.

Termenul caşs $\stackrel{u}{<}$ lat. caseus este atestat în DDA cu sensul de 'caş' (DDA S.v.).

În DA, termenul caş este definit astfel: 'substanţă alimentară cu gust acrişor, preparată din lapte de oaie (de vacă sau de capră) închegat, apoi mestecat bine, scurs de zer în strecurătoare (sau crintă), lăsat să se svinte, să lase zerul şi să dospească pe hârzob, şi uscat pe poliţă sau pe leasă. Din caş se face brânza. I Specii: caş dulce sau proaspăt sau în zer (scăpat numai de zerul cel mult): nesărat, caş sărat, caş murat, caş cu înăcreală '. Mai este menţionat faptul că dacoromânii foloseau, în vechile timpuri, termenul caş pentru toate tipurile de brânză, aşa cum procedează şi în prezent aromânii, meglenoromânii şi istroromânii. În dacoromână, sensul s-a specializat mai târziu, astfel că termenul brânză era utilizat pentru a desemna brânza sărată, iar termenul caş pentru a desemna brânza dulce sau specialităţile străine. (DA s.v.).

Termenul este atestat şi în (DELR s.v.).: CAŞ [ar. caş $\stackrel{u}{\prime}$ mr. caş, ir. cåş] s.n., s.m. „brânză dulce, proaspătă - fromage frais” 1523. Lat. cāseus, cāseum „brânză”, cf. dalm., it,, sd., sp., ptg. REW 1738 (în trecut era termenul generic pentru brânză, păstrat ca atare în ar., mr., ir.).

Ţinând seama de sensul din aromână, 'brânză sărată', dar şi de cel din dacoromână, 'brânză dulce', al lexemului caş, putem concluziona că termenul din aromână este motivat. Pentru a diferenţia mai bine cele două tipuri de brânză, cel sărat şi cel dulce, aromânii au folosit epitetul dulţi. Aşadar, aromânii utilizează termenul caş ${ }_{1}^{u}$ pentru a desemna 'brânza sărată', şi caş 'brânza dulce'.

Pentru a exemplifica mai bine noţiunile de mai sus, reproducem un fragment de text, aparţinând graiului fărşerot al dialectului aromân, transcris dialectal şi transpus în dacoromână. Materialul a fost obţinut, într-o anchetă dialectală desfăşurată în ianuarie 2019, în Constanţa, de la subiectul Cavachi Viorica (70 ani):

\section{[ d̦ă nihiám cum s-adáră cáşlu dúlţi? ]}

tóra nu mai fătém caş că âl dăm láptili / da ma nínti dúpă ţi muldéáam ứoiili // lu-alâsám nihiám di s-lâyârséá / âl trâțéám pit stâcâtoári di dáuă-trei ori / sticătoáréa s-híbă ma groásă ca s-ul aléágă ghíni di práfu di ŭbi di ţivá /ş-dapóia âl bâgám nihịám di lâ-ngâlḑám ca s-híbă monocáld / îi bâgám ca únă língură di clac ù la d̦áţi kíli di lápti / șloalâsám ca nă sáti dáuăa anvâlít // âl dizvâléám ş-vidéám căn lư-astâl'á ḑắru // âl luạm şi tu tijgéáuă ântindéám gíni sticătoárea / ş-bâgám ş-nă scấndură s-íntră // âl bâgam cáşuacó cum s-tâlá el // lu-alâsám di si scurdéáa nihiám ma ğíni // ş-dapóịa âl disfăţéám ş-când प̣ vréam sâ-l mâcắm caş dúlţi âl mâcám caş dúlţi // 
[spune-ne despre cum se face brânza dulce?]

[acum nu mai facem brânză că dăm laptele / mai înainte după ce mulgeam oile // îl lăsam să se liniştească / îl strecuram de două-trei ori / strecurătoarea să fie mai groasă ca să îndepărtăm bine praful de la oi sau altceva / după aceea îl puneam puţin la încălzit / îi puneam o lingură de cheag la zece kile de lapte / şi îl lăsam o oră-două acoperit // îl dezveleam şi vedeam dacă s-a tăiat zerul // ̂̂l luam şi întindeam bine strecurătoarea pe tejghea / îi puneam şi o scândură // puneam brânza acolo după ce o tăiam // o lăsam de se scurgea puțin mai bine // îl desfăceam când voiam să mâncăm brânză dulce//]

\section{HARTA 641. CÂINE (ciobănesc), pl. 'chien (de berger)' [915]}

Analizăm forma de singular de la chestiunea 915 [Cum îi spui la acela de pe lângă stână care latră şi care păzeşte oile de lupi...?].

S-a răspuns cu mai mulţi termeni, dar ne îndreptăm analiza asupra următorilor doi: cắne dit cupíe şi cấne di picurár !̆.

\section{cắne dit cupíe 16; cắni di cupíiii, cän 54}

Forma cắne dit cupíe este ocurentă în graiul moloviştean, iar forma cắni di cupíiil, cäń , în graiul fărşerot din Cristalopiyi. În structura cắne dit cupíe, grupul nominal dit cupíe este motivat pentru că desemnează un anumit tip de câine, pe cel care păzeşte turma.

cắni di picurár

Forma cắni di picurár Târnova, forma cắnị di picurárí în graiul fărşerot din Gramaticova de Sus, iar formele cấne di picurárí, câń în graiul pindean din Palioseli. În acest caz, grupul nominal di picurár ${ }_{\prime}^{l}$ este motivat, deoarece el denumeşte specializarea câinelui în desfăşurarea păstoritului.

Pentru o mai bună exemplificare, reproducem un fragment de text din graiul grămostean, aparţinând subiectului Maria Saramandu, din Sarighiol de Deal. Textul apare în Aromâna vorbită în Dobrogea. Texte dialectale. Glosar (Saramandu 2007: 232):

[şi-óili cári li duţéá?]

óili fúdéá ăhórýa / óili fúdéá pripáde / cu picurárlị // ș-avéá picurárí cu câñ / şi z_duţéá pit múnţâ / ș-avéá cắl'urlé-a lor li ştẹa // şi fuméinli cu cáli trițéá pi álti cắlurì //

[şi cine ducea oile?]

[oile mergeau repede / oile mergeau pe jos / cu cioban // ciobanii aveau câini / şi se duceau în munţi / şi îşi aveau drumurile lor ştiute // şi familiile mergeau cu caii pe alte drumuri //] 
Termenul cấne < lat. canis este atestat în DDA cu sensul de 'câine'. Papahagi dă exemple de expresii în care regăsim termenul cấne, pe care le şi comentează,

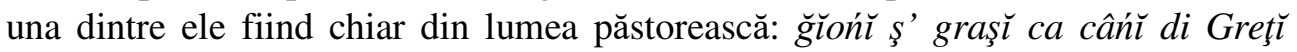
'bravi şi graşi ca câini ai grecilor': reflex din viaţa pastorală a aromânilor: spre deosebire de cei ai aromânilor, câinii grecilor, slabi, piperniciţi şi străiţi de viaţa pastoral, nu sunt în stare să înfrunte, bunăoară, fiare sălbatice (DDA s.v.).

Termenul corespunzător din dacoromână, care desemnează cel mai bine cắne dit cupíe sau cắni di picurár ${ }^{u}$, este cel de câine ciobănesc. Sensul acestuia este 1. 'care aparţine ciobanului, privitor la cioban, specific ciobanului'. 2. câine ciobănesc $=$ 'rasă de câine mare şi puternic, folosită de obicei pentru paza turmelor şi a stânii. - Cioban + suf. -esc' (DEX s.v.).

Termenul apare şi în DELR: CÂINE [ar. câne, mr. coni, cọini, coni, ir. căre, cåre] s.m. „mamifer carnivor, în general domestic - chien” 1535, var. câne. Lat. canis, cf. dalm., it., sd., ret., fr., occ., cat., galic., ptg. REW 1592 (apud DELR s.v.).

Pentru a ne lămuri mai bine, am căutat corespondenţi şi în limbile franceză, italiană, spaniolă şi germană. Am găsit astfel: fr. chien de berger, it. cane da pastore, sp. perro pastor, dar şi perro ovejero, germ. der Schäferhund. Atât termenii din cele trei limbi romanice, cât şi cel din germană sunt motivaţi, toţi desemnând corespunzător semnificatul şi se grupează după semul 'câine ciobănesc' şi după semul 'câine pentru turmă'.

HARTA 645. STRUNGĂ, pl. 'passage étroit où on fait passer les brebis une à une pour les traire' [918]

Comentăm forma de singular de la chestiunea 918 [Pe unde ies oile din îngrăditură, una câte una, ca să le mulgi?].

S-a răspuns cu mai mulţi termeni: cărare; uşă; arâstoacă; pureauă; scam.

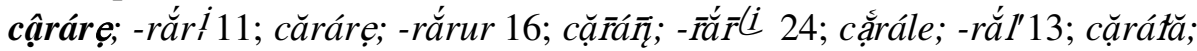
-rắt 58

Termenul cậrárẹ < lat. carraria este specific dialectului aromân, nefiind întâlnit în dialectul dacoromân cu senul de 1. 'deschizătură de ieşire din țarcul oilor, portiţă prin care poate trece numai o oaie'. - 2. 'țarc, ocol la oi'. În DDA este menţionat doar cu sensul de 'cale, drum', la fel ca în dacoromână (DA, s.v.). În ALAR, vol. II, e atestat termenul cu sensul 'deschizătură de ieşire din ţarcul oilor, portiţă prin care poate trece numai o oaie'. În aceasta constă motivarea acestui termen, care este ocurent în graiul din Cruşova, unde se vorbeşte un idiom aparte, numit ,dialect mixture” (Nevaci 2013: 109-112), în graiurile insulare (graiul din Mulovişte şi graiul din Beala de Sus), precum şi în două puncte din graiul fărşerot (Corcea, Seleniţa).

úşę; usşi 21; úşi; , [*]; úşi; 17

Termenul úşe < lat. ustium şi ostium este prezent în dialectul aromân cu sensul de 'deschizătură de formă regulată lăsată în peretele unei clădiri, la un 
vehicul, la o mobilă, pentru a permite intrarea (şi ieşirea); ansamblu format dintr-un cadru fix de care se prinde o tăblie mobilă de lemn sau de metal, care închide sau deschide această deschizătură'. Este ocurent în graiul din Nicea, dar şi în graiul grămostean din Târnova. În practica oieritului, termenul a ajuns să exprime sensul de 'strungă', desemnând locul prin care intră oile la muls. Şi în acest caz s-a produs o motivare a termenului în cauză.

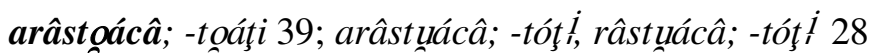

Termenul arâstoacă < lat. rostrum este întâlnit în dialectul aromân cu sensul de 1. 'deschizătură de ieşire din ţarcul oilor, portiţă prin care poate trece numai o oaie'. - 2. 'ţarc, ocol la oi' în graiul pindean, în două localităţi (Perivoli, Veria). În DDA, Tache Papahagi compară acest termen cu dacoromânescul răstoacă < vsl. rastokŭ, care are sensul de 'vârtej produs în locul unde o apă curgătoare, puţin adîncă, trece peste prund şi peste bolovani'. E puţin probabilă etimologia slavă, dacă ţinem seama că etimonul latinesc rostrum, prezintă semul /intrare/, care îl apropie de termenul aromân arâstoacă. În acelaşi timp, învelişul sonor (semnificantul) evocă semul respectiv. Acest fapt ne determină să credem că şi în acest caz este vorba de un termen motivat.

\section{pureáuăă; -rée 36}

Termenul pureáuăa este ocurent doar în graiul pindean din Aminciu. În DDA

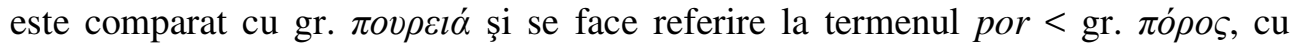
acelaşi sens 'deschizătură'.

Motivarea în acest caz se explică prin semnificantul grecesc al etimonului.

scām

Termenul $s c a \bar{m}_{!}^{U}<$ lat. scamnum este întâlnit în graiul fărşerot din Cristalopiyi. În DDA este semnalat cu sensul de 'scaun de piatră pe care stau păstorii atunci când mulg oile'. În dialectul dacoromân apare forma scaun, cu sensul 'mobilă, cu sau fără spetează, făcută pentru a şedea pe ea o singură persoană'. Menţionăm faptul că termenul din aromână nu se mai întâlneşte în nicio altă localitate, în afară de Cristalopiyi.

În acest caz sensul motivat al termenului derivă din semul 'scaun de piatră pe care stau păstorii atunci când mulg oile', legându-se astfel semantic de termenul strungă.

Termenul strungă este ocurent şi în dacoromână şi este un cuvânt de origine autohtonă; cf. alb. shtrungë, gr. $\sigma \tau \rho o v ́ \gamma \gamma \alpha$, glosat ca 1. 'deschizătură de ieşire din ţarcul oilor, portiţă prin care poate trece numai o oaie'. - 2. 'ţarc, ocol la oi'. Termenul, probabil a pornit de la cuvântul strung, în sensul de 'dispozitiv care execută frecare', fiindcă strungă face ca oile să treacă frecând stâlpul portiţei sau pe ciobanul care aşteaptă lângă el. Pentru semantism, cf. sp. torno 'instrument care 
face să treacă obiectele printr-un spaţiu închis', chiar dacă nucleul semantic al termenului spaniol este diferit. Sensul lui strung şi strungă este acelaşi de 'lucru care roade' şi este natural, dacă ne gândim că sursa comună este sl. strugati 'a răzui', cf. struji. Totuşi pentru acest cuvânt s-au propus etimoane foarte diferite. Din a strânge 'a închide' (Miklosich, Slaw. Elem., 47), dificil fonetic. - Din alb. strungë (Miklosich, Slaw. Elem. im Magyar, 35) e acelaşi lucru, deşi alb., în opinia lui Miklosich, depinde de stragoń < lat. stringĕre. Dintr-o rădăcină indo-europ. *strng- (Jokl, Sb. Wien, CLXVIII, I, 89; Barič, Albanorum St., I, 105); dintr-o rădăcină *sru- ,a fugi” (Philippide, II, 735); din gr. $\sigma \tau \varepsilon v v \gamma \alpha ́$,îngustime” (Diculescu 198) sau * $\sigma \tau \rho o ́ \gamma \gamma \alpha$ (Drăganu, Românii în veac. IX-XIV, 60; cf. Tamás, Archiv. Europ. Centro-Orient, II, 269); dintr-o rădăcină tracică *struma „curgătoare” (Pascu, I, 191); cf. Scriban; din lat. ruga contaminat cu v. germ. stranga (Giuglea, Dacor., II, 340-3). În general se admite că este cuvânt foarte vechi şi că din română s-a răspândit în alte idiomuri balcanice şi orientale, cf. Tiktin şi Candrea, şi Rosetti, II, 122. Uz general (ALR, I, 31). Der. strungar, s. m. (cioban care mână oile prin strungă); strungăreaţă, s. f. (răritură la dinţi; ciubăr de muls oile). Din rom. provin negreşit toate formele cu infixul $n$, ca ngr. $\sigma \tau \rho o v ́ \gamma \gamma \alpha$ (Meyer, Neugr. St., II, 79; Murnu, Lehnw., 43), alb. strungë (Meyer 418), ceh., slov., rut. strunga, pol. straga, mag. ezstrenga (Candrea, Elementele, 401), ven. strunga (Tiktin). Formele fără infix nazal (bg. străga, sb. straga) pot proveni şi ele dintr-o formă anterioară nazalizării, cf. strug faţă de strung, sau din sl. (apud DER s.v.).

În studiul său despre terminologia păstorească din dacoromână, Alina Celac acordă un comentariu larg termenului strungă (Celac 2007: 55-57). Autoarea semnalează prezenţa mai multor răspunsuri pentru această chestiune în graiurile sudice ale dacoromânei: strungă ţarc, uşă, poartă Termenul uşă , pe care noi l-am întâlnit în două graiuri ale dialectului aromân, în cel din Nicea şi în cel grămostean din Târnova, este ocurent în mai multe puncte din Oltenia şi Muntenia, dar şi în câteva localităţi din Dobrogea.

\section{HARTA 652. BURDUF, pl. ‘outre (de peau crue)’ [924]}

Analizăm forma de singular de la chestiunea 924 [Cum îi spui la acela făcut din piele de miel, de viţel, în care se ţine brânza? Se mai poate ţine în el sare, făină?]

S-a răspuns cu mai mulţi termeni: funale, kali, târváĉu

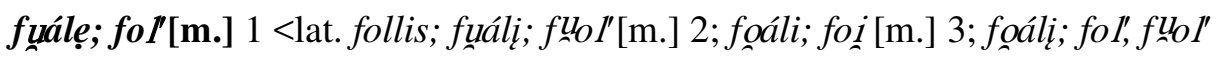
[m.] 4; foáli [m.] 5, 10; foáli; fol' [m.] 6-9, 35, 39-41; fóle; fol' [f.] 11; fúáli; funoi [m.] 12; fóle; fol' [m.] 13; fóle [m.] 14; [б] fóli. 17; fóli; fol' [m.] 18; foálí; fol' [m.] 19, 21-25, 29, 31; foále; ful'ín [pl.] 20; fúáli; fol' [m.] 28; foále; fol' [m.], útre 32; fol'll; fol' [m.] 33; foáli; fol', fóli [neart.] [m.] 36; fóli 37, 54; fóli; foi 38; foáli, [art.] foálili [m.] 49; fólį; fol'[m.] 56; fóli 59. 
Termenul funále; fol'< lat. follis este atestat în DDA cu varianta foále, având sensul de 'sac'. Am întâlnit această formă şi în DLR, cu sensul de 1. 'Sac primitiv făcut din pielea unor animale'. Şi: burduf (5). ' 2. (Reg; îs; îf foi) Stâna foilor 'Încăpere la stână în care se depozitează brânzeturile'.

Formează o arie mai mare, cuprinzând toate graiurile dialectului aromân:

- în graiul fărşerot este prezentă forma foále; ful'ín cu variantele fonetice foáli; fol' [m.]; fóle; fol' [m.]; fóle [m.]; fóli; fol', fóli; fóli; for ; fólic; fol' [m.]; fóli formând o arie cuprinzătoare (e înregistrată în localităţi din Albania (Andon Poci, Corcea, Diviaca, Ducasi, Fier, Pleasa), R. Macedonia (Nijopole, Beala de Sus, Beala de Jos), Grecia (Gramaticova de Sus, Cândrova, Cristalopiyi).

- în graiul grămostean este prezentă forma fúále; fol' cu variantele fonetice

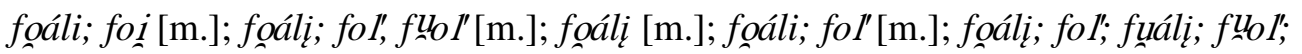
fóle; fol; $[\sigma]$ fóli, formând o arie cuprinzătoare (e înregistrată în localităţi din Bulgaria (Blagoevgrad, Papaceair, Lopova, Bachiţa, Bujdova, Razlog, Batac, Şatra), R. Macedonia (Cruşova, Ubovo, Târnova), Grecia (Livezi, Deniscu).

- în graiul pindean este prezentă forma fúáli; funoi [m.] cu variantele fonetice fúáli; fol' [m.]; foáli; fol' [m.]; foáli; fol' [m.]; foálili [m.]; foále; fol' [m.], útre; fol'lu; fol' [m.]; foáli; fol', fóli [neart.] [m.], formând o arie cuprinzătoare (e înregistrată în localităţi din Grecia precum Turia, Perivoli, Avdela, Giurgea, Xirolivad, Veria, Samarina, Palioseli, Aminciu, Cuţufleani), dar şi în Bulgaria (Poroi de Sus).

- formele foáli; fol'sunt prezente în graiurile din Nicea şi Greava (Albania).

Termenul foále este motivat pentru că desemnează obiectul în care se depozitează brânza, sarea sau făina şi prezintă semul 'sac primitiv făcut din pielea unor animale'.

\section{Káli; Ke'l[f.] 44}

Termenul Káli; Kel'este atestat în DDA cu forma keále, pl. kelĩ < lat. pellis şi este utilizat şi cu sensul de 'burduf'. Termenul este prezent în graiul pindean din Vendişte (Grecia).

Motivaţia constă în faptul că termenul káli indică materialul din care este confecţionat burduful, adică din pielea unor animale.

Pentru o mai bună exemplificare, reproducem un fragment de text din graiul grămostean, aparţinând subiectului Maria Saramandu, din Sarighiol de Deal. Textul apare în Aromâna vorbită în Dobrogea. Texte dialectale. Glosar (Saramandu 2007: 234): 


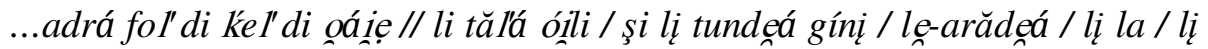

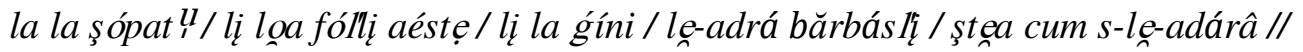
ş-l-alăsá gúrâ aoá la gúsi / ș́-li umpleá dẹapoá di...

[...făceau foale din piei de oaie // tăiau oile / şi le tundeau bine / până la piele / le spălau / le spălau la pârâu / le luau pieile ăstea / le spălau bine / le făceau bărbaţii / ştiau cum să le facă // şi le lăsa o gaură la gât / şi apoi le umpleau cu...]

\section{târváĉü -váci $[$ [n.] 52}

Termenul târváĉ sensul de 'burduşel'. îl compară cu alb. torbë, iar în privinţa etimologiei este incert oferindu-ne două variante, tc. torba şi gr. $\tau o \rho \beta \alpha ́ \varsigma, \tau \rho o v \beta \alpha \dot{\alpha} \varsigma$. Termenul este prezent în graiul fărşerot din Horopani (Grecia).

Termenul este motivat pentru că prezintă semul 'burduşel', mai exact un substantiv care desemnează un burduf de dimensiuni mai mici.

În DELR apare BURDUF s.n. ,,peritoneu; sac din piele netăbăcită - peritoine; outre" 1561 (antrop. Burduh), var. burduc, burduh, burduj, burduş, burduv. Et. nes., probabil < tăt. burduk ,,vas pentru vin”, ucr. burdjuk, burdjuh O. Densusianu, GS, 1, 1923, 349 // Probabil el. de substrat, cf. alb. burdhë,,sac” Brâncuş, VA, 135; cf. pol. brzuch „pântece”, ceh. brich(o), rus. brjucho CDED II 23-24; cf. bort, burtă, TDRG; borh-, cf. bort CDER 1029; et. nec. DA, DEX (apud DELR s.v.).

Termenul burduf este definit în MDA astfel: burduf sn [At: LB / V: bor , borduş, -duh, -duj, -duş, (reg) -duv, -tuc \} -rtuş $1 \mathrm{Pl}$ : -uri, (rar) -e / E: net] (Reg) 1. 'Peritoneul animalelor'. 2. 'Vezica bovinelor'. 3. (Pex) 'Pielea vezicii animalelor, care servea drept geam'. 4. 'Stomac'. 5. 'Sac primitiv confecţionat din stomacul animalelor, folosit la păstrarea alimentelor'. 6. 'Pungă laterală ataşată la şa.' 7. 'Parte a cimpoiului care se umflă cu aer'. 8. (Pex) 'Cimpoi'. 9. (Pex) 'Foale'. 10. (Pan) 'Pântece mare'. 11. 'Partea convexă a semilunii'. 12. 'Cutia de lemn a instrumentelor cu coarde, care produce rezonanţa tonului'. 13. 'Copil mic' (MDA s.v.). Brâncuş a încadrat acest lexem în categoria cuvintelor autohtone probabile. El propune spre analiză mai multe etimoane care ar sta la baza termenului burduf, dar consideră că alb. burdhë este cel mai potrivit.

Unul dintre sensurile atestate în MDA este cel de 'foale', termen ocurent nu numai în dacoromână, ci şi în aromână. Sensul lui este acelaşi în ambele dialecte: 'Sac primitiv făcut din pielea unor animale Si: burduf (5)'. 2 (Reg; îs; îf foi) 'Stâna foilor încăpere la stână în care se depozitează brânzeturile'.

\section{CONCLUZII}

În analizele şi comentariile noastre din această lucrare, am remarcat că toți termenii avuţi în vedere permit interpretări din perspectiva motivaţiei. $\mathrm{O}$ parte 
dintre aceştia suportă analiza din perspectiva semnificantelor, în sensul că între învelişul sonor şi semnificat există un raport motivaţional.

Legătura naturală dintre semnificat şi semnificant nu s-a opacizat. Este cazul cuvintelor cârléję ('căpuşă’), caşu dúlţi ('caş'), cắne dit cupie, cấne di picurár ('câine ciobănesc'), cărare ('strungă') etc. Pe de altă parte, la alţi termeni, relaţia motivaţională nu se referă la legătura naturală dintre semnificat şi semnificant, ci la legătura dintre un sem al sememului respectiv cu o altă formă cu sens identic sau foarte apropiat. Exemple din această categorie, analizate supra, sunt: Kali, târváĉ ('burduf'), úşă; arâstoácă; pureáuă; scam ('strungă'), căţămór ('căpuşă').

În urma încercărilor noastre în acest studiu, se conturează şi se accentuează ideea că interpretarea motivaţională a sensurilor cuvintelor şi a relaţiilor semantice dintre acestea va constitui de acum înainte o metodă binevenită de analize lexicale.

\section{BIBLIOGRAFIE}

Brâncuş 1983

Celac 2007

Dalbera 2006

Dima 2013

Moroianu 2016

Nevaci 2013

Papahagi 1979

Russu 1970

Saramandu 2007

Saramandu/Nevaci 2013

Saussure 1998
- Grigore Brâncuş, Vocabularul autohton al limbii române, Bucureşti, Editura Ştiinţifică şi Enciclopedică, 1983.

- Alina Celac, Terminologia păstoritului în graiurile dacoromâne sudice, Academia Română, Fundaţia Naţională pentru Ştiinţă şi Artă, Bucureşti, 2007.

- Jean-Philippe Dalbera, Des dialectes au langage. Une archéologie du sens, Honoré Champion Éditeur, Paris, 2006.

- Emanuela Dima, Terminologia păstorească moştenită în limba română, Bucureşti, Editura Academiei Române, 2013.

- Cristian Moroianu, Motivarea formală a relaţiilor semantice. Sinonimia analizabilă, Bucureşti, Editura Universităţii din Bucureşti, 2016.

- Manuela Nevaci, Identitate românească în context balcanic, Bucureşti, Editura Muzeului Naţional al Literaturii Române, 2013.

- Tache Papahagi, Mic dicţionar folkloric, Bucureşti, Editura Minerva, 1979.

- Ioan Iosif Russu, Elemente autohtone în limba română. Substratul comun româno-albanez, Bucureşti, Editura Academiei, 1970.

- Nicolae Saramandu, Aromâna vorbită în Dobrogea. Texte dialectale. Glosar, Bucureşti, Editura Academiei Române, 2007.

- Nicolae Saramandu, Manuela Nevaci, Sinteze de dialectologie română, Bucureşti, Editura Universitară, 2013.

- Ferdinand de Saussure, Curs de lingvistică generală, Iaşi, Editura Polirom, 1998.

\section{SURSE}

Atlasul lingvistic al dialectului aromân, vol. II, [Nicolae Saramandu, în colaborare cu Manuela Nevaci], Bucureşti, Editura Academiei Române, 2019 (sub tipar).

Atlasul lingvistic al dialectului aromân, vol III - în manuscris [Nicolae Saramandu, în colaborare cu Manuela Nevaci], Editura Academiei Române, Bucureşti.

DA - Dicţionarul limbii române, sub conducerea lui Sextil Puşcariu, tomul I, partea I: $A-B$, Academia Română, Întocmit şi publicat după îndemnul şi cu cheltuiala Maiestăţii Sale Regelui Carol I, Bucureşti, Librăriile Socec \& Comp. şi C. Sfetea, 1913; tomul I, partea II: C, 
Academia Română, Întocmit şi publicat după îndemnul şi cu cheltuiala Maiestăţii Sale Regelui Carol I, Bucureşti, Tipografia Ziarului „Universul”, 1940; tomul I, partea III, fascicula I: $D-D e$, Academia Republicii Populare Române, Bucureşti, Universul, Intreprindere Industrială a Statului, 1949; [fascicula II: De-Desţina; şpalt, 1948]; tomul II, partea I: $F-I$, [de fapt: $I / \hat{I}$, Academia Română, Întocmit şi publicat după îndemnul Maiestăţii Sale Regelui Carol I, Bucureşti, Monitorul Oficial şi Imprimeriile Statului, Imprimeria Naţională, 1934; tomul II, partea II, fascicula I: J-Lacustru, Academia Română, Întocmit şi publicat după îndemnul Maiestății Sale Regelui Carol I, București, Tipografia Ziarului „Universul” S. A., 1937; tomul II, partea II, fascicula II: Ladă-Lepăda, Academia Română, Întocmit şi publicat după îndemnul Regelui Carol I, Bucureşti, Tipografia Ziarului „Universul” S. A., 1940; tomul II, partea II, fascicula III: Lepăda-Lojniţă, Academia Republicii Populare Române, Bucureşti, Tipografia Ziarului „Universul” S. A., 1944-1945.

DAR/FSR - Renata Topciu, Luan Topciu, Ana Melonashi, Dicţionar albanez-român. Fjalor shqiprumanisht, Iaşi, Bucureşti, Editura Polirom, 2003.

DBR/БPP - Daniela Stoianova, Dicţionar bulgar-român, Sofia, 2008.

DDA - Tache Papahagi, Dicţionarul dialectului aromân, general şi etimologic, ediţia a doua augumentată, Bucureşti, 1974

DELR - Dicționarul etimologic al limbii române, vol. I, A-B, 2011, vol. II, C, partea I, Ca-Cizmă, 2015, partea a II-a, Clac-Cyborg, 2018, Bucureşti, Editura Academiei Române.

DEX - Dictionarul explicativ al limbii române, București, Editura Univers Enciclopedic, 1998.

MDA - Micul dicţionar academic, Bucureşti, Editura Univers Enciclopedic.

\title{
MOTIVATIONAL ANALYSIS \\ OF SOME PASTORAL TERMS FROM AROMANIAN DIALECT
}

\begin{abstract}
In this paper we considered the analasys of terms belonging to the Aromanian lexicon from a motivational perspective. After defining the concept of motivational analysis, for which we accessed different specialized papers, we commented the correspondents, from the Aromanian dialect, of the terms tick, cheese, shepherd dog, breach and skin. The terms were extracted from the Linguistic Atlas of the Aromanian Dialect (author: Nicolae Saramandu, editor: Manuela Nevaci). At the end of the article we was able to conclude that all the terms considered allow interpretations from the perspective of motivational analysis.
\end{abstract}

Universitatea din Bucureşti Str. Edgar Quinet nr. 3-5 
